\title{
Author Index 2007
}

B

Banwell, Karen see Stevenson, Anna

Barnett, Guy see Kearns, Allen

Beaty, Matthew see Kearns, Allen

Berry, Helen L

'Crowded suburbs' and 'killer cities': a brief review of the relationship between urban environments and mental health. 2007; 18(11-12): 222-7

Black, Megan E see Madden, D Lynne

Blakely, Edward J see Capon, Anthony G

Boufous, Soufiane see Hayen, Andrew D

Bowen, Caron

Health impact assessments in London: assessing the London Mayoral strategies. 2007; 18(9-10): 185-7

Breckenridge, Jan and Mulroney, Jane

Leaving violent relationships avoiding homelessness providing a choice for women their children. 2007; 18(5-6): 90-3

Bull, Fiona C L see Giles-Corti, Billie

Bulsara, Max see Giles-Corti, Billie

Butler, Tony G see Levy, Michael H

C

Campbell-Lloyd, Sue see Viney, Kerri A

Capon, Anthony $\mathbf{G}$ and Blakely, Edward J

Checklist for healthy sustainable communities. 2007; 18(3-4): 51-4

Capon, Anthony $G$ and Dixon, Jane M

Creating healthy, just and eco-sensitive cities. 2007; 18(3-4): 37-40

Capon, Anthony G see Dixon, Jane M

Capon, Anthony G

Health impacts of urban development: key considerations. 2007; 18(9-10): 155-6

Carlisle, Rachel see Sutherland, Emma

Chavez, Roberta V see Harris, Elizabeth

Chiu, Clayton K; Durrheim, David N

A review of the efficacy of human $\mathrm{Q}$ fever vaccine registered in Australia. 2007; 18(7-8): 133-6

Copeland, Kate $\mathbf{J}$ and Young, Andrea $M$

Health social impact assessment of the South East Queensland Regional Plan (2005-2026). 2007; 18(9-10): 177-9

Corbett, Stephen J

Channelling Edwin Chadwick: beyond utopian thinking in urban planning policy health. 2007; 18(9-10): 195-7

Cozens, Paul

Public health the potential benefits of Crime Prevention Through Environmental Design. 2007; 18(11-12): 232-7

Craig, Adam; Hall, Gillian and Russell, Richard

Bug Breakfast in the Bulletin: Climate change and infectious diseases. 2007; 18(11-12): 243-4

\section{D}

Develin, Elizabeth see Thackway, Sarah V

Dews, Carolyn L see Furber, Susan E
Dixon, Jane M and Capon, Anthony G

Healthy, just and eco-sensitive cities: moving forward. 2007; 18(11-12): 209-12

Dixon, Jane M see Capon, Anthony G

Doggett, Stephen L see Spokes, Paula J

Dubois Lorraine $\mathbf{G}$ see Gow, Andrew J

Durrheim, David N see Chiu, Clayton K

Dyball, Robert see Newell, Barry

E

Eyeson-Annan, Margo L see Norris, Tom F

$\mathrm{F}$

Flynn, Michael see McAnulty, Jeremy M

Forssman, Bradley L and Gupta, Leena

Enhanced surveillance of hepatitis B infection in innerwestern Sydney. 2007; 18(7-8): 115-8

Fuller, Jeffrey D see Heading, Gaynor S

Furber, Susan E; Gray, Erica; Harris-Roxas, Ben F;

Neville, Leonie M; Dews, Carolyn $L$ and

Thackway, Sarah V

Rapid versus intermediate health impact assessment of foreshore development plans. 2007; 18(9-10): 174-6

G

Giles-Corti, Billie; Knuiman, Matthew; Pikora, Terri J; Van Neil, Kimberly; Timperio, Anna; Bull, Fiona C L; Shilton, Trevor and Bulsara, Max

Can the impact on health of a government policy designed to create more liveable neighborhoods be evaluated? An overview of the RESIDential Environment Project. 2007; 18(11-12): 238-42

Gillham, Karen E see Wells, Venessa L

Gow, Andrew $\mathbf{J}$ and Dubois Lorraine $\mathbf{G}$

Bungendore health impact assessment: urban development in a rural setting. 2007; 18(9-10): 164-5

Gray, Erica see Furber, Susan E

Gupta, Leena see Forssman, Bradley L

$\mathrm{H}$

Hall, Gillian see Craig, Adam

Harris, Elizabeth see Harris, Patrick J

Harris, Elizabeth; Rose, Vanessa K; Kemp, Lynn A and Chavez, Roberta V

Strengthening the effectiveness of 'whole of government' interventions to break the cycle of violence in disadvantaged communities. 2007; 18(5-6): 94-6

Harris, Patrick J see Harris-Roxas, Ben F

Harris, Patrick J; Harris-Roxas, Ben F and Harris, Elizabeth

An overview of the regulatory planning system in New South Wales: identifying points of intervention for health impact assessment and consideration of health impacts. 2007; 18(9-10): 188-91

Harris, Patrick J; Harris-Roxas, Ben F and Kemp, Lynn Health impact assessment in urban settings. 2007; 18(9-10): 149-50 
Harrison, James E see Hayen, Andrew D

Harris-Roxas, Ben F and Harris, Patrick J

Learning by doing: the value of case studies of health impact assessment. 2007; 18(9-10): 161-3

Harris-Roxas, Ben F see Furber, Susan E; Harris, Patrick J

Hayen, Andrew D; Boufous, Soufiane and

Harrison, James E

A discussion of the potential benefits to injury surveillance through inclusion of date of injury in hospitalisation data in New South Wales, Australia. 2007; 18(7-8): 130-2

Heading, Gaynor S; Fuller, Jeffrey D; Lyle, David M and Madden, D Lynne

Using problem-based learning in public health service based training. 2007; 18(1-2): 8-13

Hecker, Richard see Madden, D Lynne

Howe, Renate T

Developing a national approach to building healthy and sustainable cities. 2007 ; 18(3-4): 45-7

Hughes, Jenny L and Kemp, Lynn A

Building health impact assessment capacity as a lever for healthy public policy in urban planning. 2007; 18(9-10): 192-4

I

Irwin, Melissa J; Lloyd, Andrew R and Massey, Peter D Bug Breakfast in the Bulletin: Q fever. 2007; 18(7-8): $137-8$

\section{$J$}

Jones, Thérèse see Liddle, Jeannine

$\mathrm{K}$

Kardamanidis, Katina; Smith, Mitchell M and Vagholkar, Sanjyot

Bug Breakfast in the Bulletin: refugee health. 2007; 18(1-2): 26-27

Kearns, Allen; Beaty, Matthew and Barnett, Guy

A social-ecological perspective on health in urban environments. 2007 ; 18(3-4): 48-50

Kemp, Lynn A see Harris, Elizabeth; Harris, Patrick J; Hughes, Jenny L

Kempton, Anne M see Wells, Venessa L

Knuiman, Matthew see Giles-Corti, Billie

\section{L}

Lesjak, Margaret see Liddle, Jeannine

Levy, Michael H; Butler, Tony G and Zhou, Jialun Prevalence of Mantoux positivity and annual risk of infection for tuberculosis in New South Wales prisoners, 1996-2001. 2007; 18(7-8): 119-24

Licata, Milly see Wells, Venessa L

Liddle, Jeannine; Lyle, David; Lesjak, Margaret; Milat, Andrew; Webster, Emma and Jones, Thérèse Influencing population health performance: introduction of standards for area health services in New South Wales. 2007; 18(1-2): 17-21

Lloyd, Andrew R see Irwin, Melissa J

Loughrey, Bernadette see Strazdins, Lyndall

Lyle, David M see Heading, Gaynor S; Liddle, Jeannine

$\mathrm{M}$

Madden, D Lynne see Heading, Gaynor S; Naylor, Carlie-Jane
Madden, D Lynne

Strengthening learning opportunities to promote the capacity of the public health workforce. 2007; 18(1-2): 2-3

Madden, D Lynne; Black, Megan E; Naylor, Carlie-Jane and Hecker, Richard

Future directions for the Bulletin. 2007; 18(1-2): 1-2

Massey, Peter D see Irwin, Melissa J

Maxwell, Michelle L

A health impact assessment of the Liverpool Hospital redevelopment. 2007; 18(9-10): 172-3

McAnulty, Jeremy $M$ and Flynn, Michael

Health surveillance among a team of Australian health workers assisting tsunami victims in Aceh, Indonesia. 2007; 18(1-2): 22-4

McAnulty, Jeremy M see Viney, Kerri A

McCaffery, Kirsten see Wallace, Cate

McCormick, Jessica

Lessons in applying health impact assessment to regeneration schemes: the Victorian experience. 2007; 18(9-10): 180-1

McManus, Phil see Newell, Barry

McMichael, Anthony J

Will considerations of environmental sustainability revitalise the policy links between the urban environment and health? 2007; 18(3-4): 41-5

Milat, Andrew see Liddle, Jeannine; Thackway, Sarah V

Mulroney, Jane see Breckenridge, Jan

$\mathrm{N}$

Naylor, Carlie-Jane see Madden, D Lynne

Naylor, Carlie-Jane; Madden, D Lynne and

Oong, Deborah J

Use of communication technology among public health professionals in New South Wales, Australia. 2007; 18(1-2): 13-6

Neville, Leonie M see Furber, Susan E

Newell, Barry; Proust, Katrina; Dyball, Robert and

McManus, Phil

Seeing obesity as a systems problem. 2007; 18(11-12): 214-8

Newman, Christine see Tennant, Kay

Norris, Tom F and Eyeson-Annan, Margo L

Recent substance use and high levels of psychological distress among secondary school students in New South Wales. 2007; 18(7-8): 125-9

0

Oong, Deborah J see Naylor, Carlie-Jane

P

Pikora, Terri J see Giles-Corti, Billie

Pink, Ramon see Stevenson, Anna

Proust, Katrina see Newell, Barry

$\mathrm{R}$

Rose, Vanessa K see Harris, Elizabeth

Russell, Richard see Craig, Adam

Rutherford, Alison and Zwi, Anthony B

How can the health sector respond to violence? 2007; 18(5-6): 73-4 
Rutherford, Alison and Zwi, Anthony B

Preventing violence in New South Wales: data sources their adequacy. 2007; 18(5-6): 75-82

\section{S}

Shilton, Trevor see Giles-Corti, Billie

Smith, Mitchell M see Kardamanidis, Katina

Spangaro, Joanne M

The NSW Health routine screening for domestic violence program. 2007; 18(5-6): 86-9

Spokes, Paula J; Doggett, Stephen $L$ and

Webb, Cameron E

Bug Breakfast in the Bulletin: Ross River virus. 2007; 18(3-4): 63-4

Stevenson, Anna; Banwell, Karen and Pink, Ramon

Greater Christchurch Draft Urban Development Strategy 2005. 2007; 18(9-10): 182-4

Strazdins, Lyndall and Loughrey, Bernadette

Too busy: why time is a health and environmental problem. 2007; 18(11-12): 219-21

Sutherland, Emma and Carlisle, Rachel

Healthy by Design: an innovative planning tool for the development of safe and accessible attractive environments. 2007; 18(11-12): 228-31

\section{T}

\section{Tennant, Kay and Newman, Christine}

Greater Granville Regeneration Strategy. 2007; 18(9-10): 169-71

Thackway, Sarah V see Furber, Susan E

Thackway, Sarah V; Milat, Andrew J and

Develin, Elizabeth

Influencing urban environments for health: NSW Health's response. 2007 ; 18(9-10): 150-1

Thompson, Susan

A planner's perspective on the health impacts of urban settings. 2007; 18(9-10): 157-60

Timperio, Anna see Giles-Corti, Billie

Trevena, Lyndal J

Problem-based learning in public health workforce training: a discussion of educational principles and evidence. 2007 ; $18(1-2)$ : $3-8$
$\mathrm{V}$

Vagholkar, Sanjyot see Kardamanidis, Katina

Van Neil, Kimberly see Giles-Corti, Billie

Viney, Kerri A; McAnulty, Jeremy $M$ and Campbell-Lloyd, Sue

Pertussis in New South Wales, 1993-2005: the impact of vaccination policy on pertussis epidemiology. 2007; 18(3-4): 55-61

Vohra, Salim

International perspective on health impact assessment in urban settings. 2007 ; $18(9-10)$ : 152-4

W

Wallace, Cate; Weisberg, Edith and McCaffery, Kirsten Bug Breakfast in the Bulletin: Human Papilloma Virus. 2007; 18(5-6): 97-8

Webb, Cameron E see Spokes, Paula J

Webster, Emma see Liddle, Jeannine

Weisberg, Edith see Wallace, Cate

Wells, Venessa L; Gillham, Karen E; Licata, Milly and Kempton, Anne M

An equity-focussed social impact assessment of the Lower Hunter Regional Strategy. 2007; 18(9-10): 166-8

Wiggers, John H

Reducing alcohol-related violence improving community safety: the Alcohol Linking Program. 2007; 18(5-6): $83-5$

Y

Young, Andrea M see Copeland, Kate J

Z

Zhou, Jialun see Levy, Michael H

Zwi, Anthony B see Rutherford, Alison 